\title{
PENGEMBANGAN SUBJECT SPESIFIC PEDAGOGY TEMATIK UNTUK MENINGKATKAN KEJUJURAN DAN KEDISIPLINAN SISWA KELAS I SD
}

\section{DEVELOPING THEMATIC SUBJECT-SPECIFIC PEDAGOGY TO IMPROVE GRADE I STUDENTS' HONESTY AND DISCIPLINE}

\author{
Paimun, Muhsinatun Siasah Masruri \\ SD Negeri Wonosari I Gunungkidul, Universitas Negeri Yogyakarta \\ paimunwonosari@yahoo.co.id, muhsinsiasah@gmail.com
}

\begin{abstract}
Abstrak
Penelitian ini bertujuan untuk menghasilkan perangkat pembelajaran terpadu berupa Subject Spesific Pedagogy (SSP) Tematik yang dapat meningkatkan karakter siswa kelas I sekolah dasar terutama karakter jujur dan disiplin. Penelitian ini merupakan penelitian dan pengembangan, yang terdiri atas sembilan tahap, yaitu: (1) penelitian dan pengumpulan data, (2) perencanaan, (3) pengembangan draft produk, (4) uji coba lapangan awal, (5) merevisi hasil uji coba, (6) uji coba lapangan, (7) penyempurnaan produk hasil uji coba lapangan, (8) uji pelaksanaan lapangan, dan (9) penyempurnaan produk akhir. Subjek uji coba adalah siswa kelas I SDN Wonosari I Gunungkidul Yogyakarta. Subjek uji coba satu-satu terdiri atas 3 siswa. Subjek uji coba kelompok kecil terdiri atas 10 siswa yang belum terlibat dalam uji coba satu-satu, dan subjek uji lapangan terdiri atas 47 siswa dari kelas I.B dan kelas I.C. Hasil penelitian ini berupa SSP yang meliputi: silabus, RPP, LKS, dan instrumenpenilaian. Hasil penilaian menunjukkan bahwa silabus yang dikembangkanberkategori baik. RPP yang dikembangkan berkategori sangat baik, LKS yang dikembangkan berkategori sangat baik dan instrumen penilaian yang dikembangkan berkategori sangat baik, media pembelajaran yang di-kembangkan berkategori baik. Dengan demikian dapat dinyatakan bahwa SSP yang dikembangkan berkategori baik dan sangat baik, untuk meningkatkan karakter siswa. Rata-rata hasil belajar afektif siswa untuk karakter jujur, adalah 99,50 dan disiplin adalah 98,66.
\end{abstract}

Kata Kunci: pengembangan, SSP, tematik, karakter

\begin{abstract}
This study aims to produce integrated learning kits in the form of thematic Subject-Specific Pedagogy (SSP) capable of improving the characters of Grade I students of the elementary school, especially those of honesty and discipline. This was a research and development $(R \& D)$ study consisting of nine stages, namely: (1) preliminary study and data collection, (2) planning, (3) product draft development, (4) preliminary field tryout, (5) revision of the tryout result, (6) field tryout, (7) product finalization based the field tryout result, (8) field implementation testing, and (9) final product finalization. The tryout subjects were Grade I students of SDN Wonosari I Gunungkidul, Yogyakarta. The one-to-one tryout subjects consisted of three students. The small-group tryout subjects consisted of ten students who were not involved in the one-to-one tryout. The field tryout subjects consisted of 47 students from Grade I B and Grade I C.The result of the study is in the form of SSP consisting of a syllabus, lesson plans, student worksheets, and assessment instruments. The results of the evaluation show that the developed syllabus is good. The developed lesson plans are very good, the developed student worksheets are very good, the developed assessment instruments are very good, and the developed learning media are good. Therefore, it can be concluded that the developed SSP is in the good and very good categories to improve students' characters. The students' average affective learning outcomes are 99.50 for honesty and 98.66 for discipline.
\end{abstract}

Keywords: development, SSP, thematic, characters 


\section{Pendahuluan}

Pembangunan karakter bangsa merupakan hal yang sangat penting. Menurut Undang-undang Nomor 20 tahun 2003 tentang Sistem Pendidikan Nasional pasal 3 menegaskan bahwa: Pendidikan nasional berfungsi mengembangkan kemampuan dan membentuk watak serta peradaban bangsa yang bermartabat dalam rangka mencerdaskan kehidupan bangsa, bertujuan untuk berkembangnya potensi peserta didik agar menjadi manusia yang beriman dan bertakwa kepada Tuhan Yang Maha Esa, berakhlak mulia, sehat, berilmu, cakap, kreatif, mandiri, dan menjadi warga negara yang demokratis serta bertanggung jawab. Tujuh watak (karakter) yang diamanatkan oleh undangundang tersebut: (1) beriman, bertaqwa kepada Tuhan Yang Maha Esa dan berakhlak mulia. (2) sehat. (3) berilmu (4) cakap. (5) kreatif. (6) mandiri. (7) menjadi warga negara yang demokratis serta bertanggungjawab.

Upaya untuk mewujudkan tujuh karakter tersebut, dilakukan mulai dari pendidikan dasar yaitu jenjang pendidikan yang ditempuh selama 6 tahun sejak anak berusia 6 atau 7 tahun. Pelaksanaan Kurikulum 2013 pada Sekolah Dasar/Madrasah Ibtidaiyah dilakukan melalui pembelajaran dengan pendekatan tematik-terpadu dari kelas I sampai kelas VI. Mata pelajaran Pendidikan Agama dan Budi Pekerti dikecualikan untuk tidak menggunakan pembelajaran tematik terpadu. Pembelajaran tematik-terpadu merupakan pendekatan pembelajaran yang mengintegrasikan berbagai kompetensi berbagai mata pelajaran ke dalam berbagai tema.

Pembelajaran tematik dapat diartikan suatu kegiatan pembelajaran dengan mengintegrasikan materi beberapa mata pelajaran dalam satu tema/topik pembahasan. Pembelajaran tematik dilakukan dengan maksud sebagai upaya untuk memperbaiki dan meningkatkan kualitas pendidikan, terutama untuk mengimbangi padatnya materi kurikulum. Disamping itu pembelajaran tematik akan memberi peluang pembelajaran terpadu yang lebih menekankan pada partisipasi/keterlibatan siswa dalam belajar. Keterpaduan dalam pembelajaran ini dapat dilihat dari aspek proses atau waktu, aspek kurikulum, dan aspek belajar mengajar.

Pembelajaran tematik dimaksudkan agar pembelajaran lebih bermakna dan utuh. Pembelajaran tematik ini memiliki peran yang sangat penting dalam meningkatkan perhatian, aktivitas belajar, dan pemahaman siswa terha- dap materi yang dipelajarinya, karena pembelajarannya lebih berpusat pada siswa, memberikan pengalaman langsung kepada siswa, pemisahan mata pelajaran tidak begitu jelas, menyajikan konsep dari berbagai mata pelajaran dalam suatu proses pembelajaran, bersifat fleksibel, hasil pembelajaran dapat berkembang sesuai dengan minat, dan kebutuhan siswa.

Likcona (1991, p.24) menyatakan bahwa: As even kids in kindergarten can understand why there is a need for authority, what would happen on the playground if there were no rules, and what makes a good rule. law in free society develops and disseminates classroom curricula for kindergarten through twelfth grade, explaining concepts such as authority, justice, privacy, responsibility, freedom, diversity, property, and participation.

Penanaman konsep yang paling awal di sekolah dasar terjadi pada kelas I, II, dan III yang biasa disebut dengan kelas rendah. Berdasarkan teori perkembangan kognitif Piaget dalam Schunk, DH. (2012, p.333), pada usia tersebut siswa berada pada awal tahap concrete operational (operasional konkret) ditandai dengan pertumbuhan kognitif yang luar biasa dan merupakan tahapan formatif dalam pendidikan di sekolah, karena ini masanya bahasa dan penguasaan keterampilan-keterampilan dasar anak-anak bertambah cepat secara dramatis. Hal yang logis tersebut dapat didapatkan melalui kegiatan-kegiatan yang konkret dan bermakna. Oleh karena itu, dibutuhkan cara penanaman konsep secara kongkret untuk peserta didik kelas rendah tersebut.

Pengintegrasian pendidikan karakter jujur dan disiplin pada setiap mata pelajaran, menjadi sangat penting demi kesiapan siswa dalam menghadapi setiap permasalahan dalam kehidupannya. Beberapa kasus kriminal yang melibatkan anak usia sekolah menjadi bukti empirik betapa pentingnya penanaman karakter jujur dan disiplin dalam kegiatan pembelajaran di sekolah. Salah satu usaha guru dalam mengintegrasikan karakter jujur dan disiplin ke dalam kegiatan pembelajaran di sekolah dasar adalah dengan menyusun perangkat pembelajaran Subject Specific Pedagogy (SSP) Tematik, mengingat anak usia sekolah dasar merupakan usia yang sangat peka terhadap proses imitasi. Oleh karena itu, guru diharapkan dapat menjadi fasilitator dan menjadi model yang baik bagi siswanya dalam melakukan pembiasaan perilaku baik. Selain itu penanam- 
an karakter jujur dan disiplin hal itu sejalan dengan semangat pembangunan karakter.

Pembangunan karakter bangsa yang dicetuskan pemerintah yang tertuang dalam rencana strategis kementerian pendidikan nasional 2010-2014 melalui arah kebijakan pembangunan pendidikan nasional tahun 2010-2014 yang salah satu intinya adalah penerapan pendidikan karakter bangsa (Renstra Depdiknas 2010-2014, p.35). Pendidikan karakter jujur dan disiplin merupakan bagian penting dari pendidikan karakter dari Renstra Depdiknas tersebut.

Berdasarkan pengalaman menjadi guru SD di SDN Wonosari I Gunungkidul Daerah Istimewa Yogyakarta sejak tahun 1991 sampai dengan saat ini Rencana Pelaksanaan Pembelajaran (RPP) guru belum secara eksplisit memasukkan pendidikan karakter, khususnya jujur dan disiplin. Siswa hanya dibekali dengan pengetahuan kognitif semata dan bukan keterampilan proses sebagai kunci dari pengembangan karakter peserta didik. SDN Wonosari I Gunungkidul tempat peneliti bekerja, terjadi: (1) Pendidikan karakter jujur dan disiplin belum diintegrasikan di dalam langkah-langkah pembelajaran; (2) Belum disusun rencana pelaksanaan pembelajaran berupa perangkat Subject Spesific Pedagogy (SSP) Tematik secara utuh (holistik), sehingga pendidikan karakter jujur dan disiplin yang terintegrasi dalam pembelajaran belum terlaksana; (3) Terdapat kelemahan mengintegrasikan pendidikan karakter dalam semua bidang yaitu kurangnya kemampuan guru dalam mengembangkan SSP yang utuh (holistik); (4) Terdapat kelemahan dalam mengintegrasikan pendidikan nilai sehingga perlu dikembangkan materi ajar yeng mengintegrasikan pendidikan karakter; (5) Pendidikan nilai yang diajarkan masih menekankan kemampuan kognitif dan belum meningkat ke ranah sikap (afektif) dan perilaku (psikomotorik), padahal kesuksesan pendidikan karakter tercermin dalam sikap dan perilaku peserta didik; dan (6) Guru masih menerapkan pendekatan teacher centered, sehingga pengembangan keterampilan proses yang menjadi pintu masuk pendidikan karakter jujur dan disiplin terkendala. Yang dilakukan dari hari ke hari hanyalah guru menjelaskan, kemudian murid disuruh mengerjakan tugas. Setelah semua murid selesai mengerjakan tugas, guru mengoreksi pekerjaan siswa, dan memberi skor. Berdasarkan kenyataan tersebut diperlukan model pembelajaran terpadu yang mengguna- kan tema untuk mengaitkan beberapa mata pelajaran sehingga dapat memberikan pengalaman bermakna kepada siswa berupa SSP Tematik.

Berdasarkan masalah yang teridentifikasi maka penelitian ini difokuskan pada Pengembangan SSP Tematik yang meliputi silabus, RPP, LKS, dan instrumen penilaian kelas 1 SD.Tujuan penelitian ini adalah: (1) Menghasilkan perangkat SSP Tematik yang layak untuk meningkatkan kejujuran dan kedisiplinan siswa Sekolah Dasar kelas. (2) Mengetahui keefektifan SSP Tematik yang dikembangkan untuk meningkatkan kejujuran dan kedisiplinan siswa kelas $1 \mathrm{SD}$

SSP pertama kali dikenalkan oleh Shulman sebagai Pedagogical Content Knowledge (PCK). Shulman memperkenalkan PCK "as a spesific category of knowledge "which goes beyond knowledge of subject matter per se to the dimension of subject matter knowledge for teaching" (Driel,. Verloop, \& de Vos 1998, p.675). Maksud dari pernyataan tersebut PCK disusun tidak hanya berdasarkan pengetahuan akan materi isi (mata pelajaran) tetapi di dalamnya dimasukkan juga pengetahuan tentang pengajaran materi tersebut.

SSP sebagai produk, ditampilkan dalam bentuk pengemasan bidang studi menjadi perangkat pembelajaran yang komprehensif mencakup kompetensi inti, materi, strategi, metode, media, serta evaluasi (instrumen penilaian hasil belajar). SSP meliputi: silabus, Rencana Pelaksanaan Pembelajaran (RPP), Lembar Kerja Siswa, dan Instrumen penilaian.

Karakter berasal dari Bahasa Yunani kharasseein yang, menandai sebuah tanda dengan jelas. Bohlin (2005, p.159) menyatakan bahwa, Character is that distinctive mark of our person; the combination of these distinguishing qualities that make us who we are. Character is deeper than appearance and reputation and constitutes more than our personality or temperament.

Pernyataan tersebut mengandung makna bahwa karakter merupakan ciri khas seseorang yang membedakan kualitas antar individu. Lebih lanjut pernyataan tersebut juga menekankan bahwa karakter tidak hanya apa yang terlihat di permukaan, melainkan lebih ke dalam yakni kepribadian individu tersebut.

Menurut Pusat Kurikulum (2009, p.9) jujur adalah perilaku yang didasarkan pada upaya menjadikan dirinya sebagai orang yang selalu dapat dipercaya dalam perkataan, tin- 
dakan, dan pekerjaan. Karena itu, jujur sesungguhnya berkaitan erat dengan nilai kebenaran, termasuk di dalamnya kemampuan mendengarkan, sebagaimana kemampuan berbicara, serta setiap perilaku yang bisa muncul dari tindakan manusia. Secara sederhana, kejujuran bisa diartikan sebagai sebuah kemampuan untuk mengekpresikan fakta-fakta dan keyakinan pribadi sebaik mungkin sebagaimana adanya. Sikap ini terwujud dalam perilaku, baik jujur terhadap orang lain maupun terhadap diri sendiri (tidak menipu diri), serta sikap jujur terhadap motivasi pribadi maupun kenyataan batin dalam diri seorang individu.

Menurut Pusat Kurikulum (2009, p.9) disiplin adalah tindakan yang menunjukkan perilaku tertib dan patuh pada berbagai ketentuan dan peraturan. Hurlock (2002, p.85) menyatakan bahwa disiplin terdiri dari empat unsur yaitu: peraturan, hukuman, penghargaan dan konsistensi.

Anak-anak yang memasuki kelas satu berada dalam periode transisi dari pertumbuhan masa usia prasekolah ke tahap anak usia sekolah dasar. Perkembangan fisik anak pada masa sekolah awal mengalami perlambatan jika dibandingkan dengan perkembangan pada masa prasekolah. Perkembangan mental dan sosial anak pada masa sekolah awal ini, berbanding terbalik dengan perkembangan fisik anak. Menurut Slavin (2009, p.100), pembelajaran kooperatif bukan hanya sebuah teknik pengajaran yang ditujukan untuk meningkatkan pencapaian prestasi para siswa, ini juga merupakan cara untuk menciptakan keceriaan, lingkungan yang prososial di dalam kelas.

\section{Metode Penelitian}

\section{Model Pengembangan}

Penelitian ini menggunakan model penelitian dan pengembangan (research and development). Borg \& Gall (2003, p.569) mendefinisikan Educational $R \& D$ is an industry based development model in which the findings of the research are use to design new products and procedures, which then are systematically fieldtested,evaluated, and refined until they meet specified criteria of effectiveness, quality, or similar standards.

Penelitian pengembangan produk Subject Specific Pedagogy Tematik untuk meningkatkan karakter jujur dan disiplin siswa kelas I sekolah dasar ini mengacu pendapat Borg \& Gall yang terdiri atas 10 (sepuluh) tahapan yang meliputi: (1) penelitian dan pengumpulan data, (2) perencanaan, (3) pengembangan draft produk, (4) uji coba lapangan awal, (5) merevisi hasil uji coba. (6) uji coba lapangan, (7) penyempurnaan produk hasil uji coba lapangan, (8) uji pelaksanaan lapangan, dan (9) penyempurnaan produk akhir, dan (10) desiminasi dan implementasi yang akan dilakukan oleh peneliti berikutnya pada kelompok penelitian hibah tahun ketiga.

\section{Desain Uji Coba}

(a) Validasi oleh ahli materi, (b) validasi oleh ahli media pembelajaran, (c) analisis konseptual, (d) revisi 1, (e) evaluasi perorangan, (f) analisis hasil evaluasi perorangan, (g) revisi II, (h) uji coba kelompok kecil, (i) analisis hasil uji coba kelompok kecil, (j) revisi III, (k) uji coba lapangan, (l) analisis hasil uji coba lapangan, (m) revisi IV, (n) produk akhir Subjek Uji Coba

Subjek uji coba adalah tiga orang guru mitra dan siswa kelas I SDN Wonosari I Gunungkidul, Yogyakarta terdiri atas tiga kelas. Uji coba satu-satu dilakukan terhadap 3 orang siswa. Uji coba kelompok kecil dilakukan terhadap 10 orang siswa. Uji coba lapangan dilakukan terhadap 47 orang siswa

\section{Jenis Data}

Data penelitian ini berupa data validasi ahli mengenai kelayakan produk yang dikembangkan berupa $S S P$, angket penilaian guru terhadap SSP Tematik yang dikembangkan, data respon siswa terhadap pembelajaran, data hasil pengamatan perilaku berkarakter, dan observasi penilaian karakter.

\section{Instrumen Pengumpulan Data}

Instrumen penelitian dibagi menjadi dua macam yang masing-masing digunakan untuk memenuhi kriteria kelayakan dan keefektifan produk SSP Tematik. Seluruh lembar validasi yang digunakan dalam penelitian ini digunakan untuk memvalidasi SSP dan instrumen penelitian. Validasi SSP melibatkan ahli materi pelajaran dan ahli media pembelajaran. Lembar validasi yang digunakan adalah: (1) lembar validasi silabus, (2) lembar validasi RPP, (4) lembar validasi LKS, dan (5) lembar validasi instrumen penilaian.

Instrumen untuk mengukur keefektifan SSP Tematik adalah angket penilaian guru, respon siswa, tes hasil belajar, lembar pengamatan karakter siswa, observasi penilaian karakter 
Teknik Analisis Data

Penelitian ini data dianalisa untuk mendapatkan perangkat pembelajaran berupa $S S P$ yang layak dan efektif. Apabila kedua syarat ini terpenuhi, produk SSP yang dikembangkan layak untuk digunakan. Adapun langkahlangkah yang dilakukan untuk memenuhi kedua kriteria terhadap produk SSP yang dikembang- kan adalah: (a) Data berupa skor dari para ahli diperoleh melalui lembar validasi. 3) Total skor aktual yang diperoleh kemudian dikonversikan menjadi data kuantitatif skala lima.

Menurut Sukardjo (2005, p.55) skor yang diperoleh kemudian dikonversikan menjadi nilai pada skala 5, dengan acuan tabel sebagai berikut:

Tabel 1. Konversi Skor Aktual Menjadi Skor Skala Lima Berdasarkan Simpangan Baku (SB)

\begin{tabular}{ccc}
\hline Interval Skor & Nilai & Kategori \\
\hline $\mathrm{X}>\mathrm{Mi}+1,8 \mathrm{Sbi}$ & $\mathrm{A}$ & Sangat baik \\
$\mathrm{Mi}+0,6 \mathrm{SBi}<\mathrm{X} \leq \mathrm{Mi}+1,8 \mathrm{SBi}$ & $\mathrm{B}$ & Baik \\
$\mathrm{Mi}-0,6 \mathrm{SBi}<\mathrm{X} \leq \mathrm{Mi}+0,6 \mathrm{SBi}$ & $\mathrm{C}$ & Cukup baik \\
$\mathrm{Mi}-1,8 \mathrm{SBi}<\mathrm{X} \leq \mathrm{Mi}-0,6 \mathrm{SBi}$ & $\mathrm{D}$ & Kurang baik \\
$\mathrm{X} \leq \mathrm{Mi}-1,8 \mathrm{SBi}$ & $\mathrm{E}$ & Sangat kurang baik \\
\hline
\end{tabular}

Keterangan:

$\mathrm{X}=$ skor aktual (empiris)

Mi = mean ideal, dihitung dengan menggunakan rumus :

Mi $\quad=1 / 2($ skor maksimal ideal + skor minimal ideal $)$

$\mathrm{SBi}=$ simpangan baku ideal, ditentukan dengan rumus:

$\mathrm{SBi}=1 / 6$ (skor maksimal ideal skor minimal ideal

Skala 5 tersebut tersebut diketahui bahwa skor maksimal ideal $=5$ dan skor minimal ideal $=1$, sehingga diperoleh perhi-tungan mi dan SBi sbb:

$$
\begin{aligned}
& \mathrm{Mi}=1 / 2(5+1)=3 \\
& \mathrm{Sbi}=1 / 6(5-1)=0,67
\end{aligned}
$$

\section{Hasil Penelitian dan Pembahasan}

Data Uji Coba

Pengembangan Subject Specific Pedagogy (SSP) dimaksudkan untuk membuktikan kelayakan dan keefektifan SSP dalam meningkatkan karakter siswa kelas I Sekolah Dasar. Pengembangan SSP dalam mengembangkan karakter siswa kelas I SD dilakukan dengan metode Research and Development model Borg $\&$ Gall. Penelitian dan pengembangan merupakan bentuk pengembangan berdasarkan hasil penelitian yang digunakan untuk merancang produk dan tata cara baru, yang kemudian diujicobakan, dievaluasi, dan diperhalus secara sistematis sampai mendapatkan kriteria khusus yang efektif, berkualitas atau standar yang sama (Borg \& Gall 2003, p.569)

Deskripsi Awal

Deskripsi Tahap Pendefinisian (Define) : analisis Siswa, analisis kurikulum, analisis materi, analisis jenis perangkat SSP. Deskripsi tahap perancangan (design): pemilihan format, penentuan perangkat pembelajaran, perancang- an SSP (silabus, RPP, LKS, dan instrumen penilaian.

Data Hasil Evaluasi Produk

Data yang diperoleh dalam penelitian pengembangan ini merupakan data hasil evaluasi kelayakan produk yang dilakukan oleh ahli mata pelajaran, dan ahli media pembelajaran. Data hasil evaluasi kelayakan produk berupa lembar penilaian guru dan lembar respon siswa, lembar pengamatan karakter dan lembar observasi penilaian karakter siswa terhadap SSP yang dikembangkan. Berikut data hasil penelitian pengembangan SSP Tematik untuk meningkatkan kejujuran dan kedisiplinan siswa kelas I SD.

Tabel 2. Data Hasil Evaluasi SSP oleh Ahli Materi Pelajaran

\begin{tabular}{llcl}
\hline No & $\begin{array}{c}\text { Komponen } \\
\text { SSP }\end{array}$ & $\begin{array}{c}\text { Total Skor } \\
\text { Aktual (X) }\end{array}$ & $\begin{array}{c}\text { Kategori } \\
\text { Kevalidan }\end{array}$ \\
\hline 1 & Silabus & 48 & Baik \\
2 & RPP & 82 & Sangat baik \\
3 & LKS & 48 & Sangat baik \\
4 & Instrumen & Valid & Sangat baik \\
& Penilaian & & \\
\hline
\end{tabular}


Tabel 3. Data Hasil Evaluasi SSP oleh Ahli Media Pembelajaran

\begin{tabular}{llcl}
\hline No & $\begin{array}{c}\text { Komponen } \\
\text { SSP }\end{array}$ & $\begin{array}{c}\text { Total Skor } \\
\text { Aktual (X) }\end{array}$ & $\begin{array}{c}\text { Kategori } \\
\text { Kevalidan }\end{array}$ \\
\hline 1 & Silabus & & \\
2 & RPP & & \\
3 & LKS & 67 & Baik \\
4 & Instrumen & & \\
& Penilaian & & \\
\hline
\end{tabular}

Tabel 4. Data Kelayakan SSP Lembar Penilaian Guru dan Respon Siswa oleh Ahli Mata Pelajaran

\begin{tabular}{clcc}
\hline No & $\begin{array}{c}\text { Komponen } \\
\text { SSP }\end{array}$ & $\begin{array}{c}\text { Penilaian } \\
\text { Kelayakan }\end{array}$ & $\begin{array}{c}\text { Kategori } \\
\text { Kevalidan }\end{array}$ \\
\hline \multirow{2}{*}{$\begin{array}{l}\text { Lembar } \\
\text { penilaian } \\
\text { guru }\end{array}$} & $\begin{array}{c}\text { Valid dengan } \\
\text { revisi }\end{array}$ & Baik \\
2 & Respon siswa & $\begin{array}{c}\text { Valid dengan } \\
\text { revisi }\end{array}$ & Baik \\
\hline
\end{tabular}

Tabel 4. Data Kelayakan SSP Lembar observasi karakter dan Format observasi karakter oleh Ahli Mata Pelajaran

\begin{tabular}{cccc}
\hline No & $\begin{array}{c}\text { Komponen } \\
\text { SSP }\end{array}$ & $\begin{array}{c}\text { Penilaian } \\
\text { Kelayakan }\end{array}$ & $\begin{array}{c}\text { Kategori } \\
\text { Kevalidan }\end{array}$ \\
\hline \multirow{2}{*}{1} & $\begin{array}{l}\text { Lembar } \\
\text { observasi } \\
\text { karakter }\end{array}$ & $\begin{array}{c}\text { Valid dengan } \\
\text { revisi }\end{array}$ & Baik \\
& $\begin{array}{l}\text { Format } \\
\text { observasi } \\
\text { karakter }\end{array}$ & $\begin{array}{c}\text { Valid dengan } \\
\text { revisi }\end{array}$ & Baik \\
\hline
\end{tabular}

Data Uji Coba Satu-Satu

Uji coba satu-satu dilakukan untuk memperoleh data terkait SSP yang dikembangkan. Adapun yang menjadi subjek uji coba adalah siswa kelas I SDN Wonosari I UPT TK dan SD Kecamatan Wonosari D. I Yogyakarta berjumlah 3 siswa. Hasil yang diperoleh pada uji coba satu-satu berupa data mengenai keefektifan SSP.

Pengukuran keefektifan SSP dilakukan dengan cara pengisian angket penilaian guru terhadap SSP dan respon siswa terhadap proses pembelajaran, pengisian lembar pengamatan karakter siswa oleh pengamat dan angket penilaian karakter oleh observer. Selain itu, pengukuran keefektifan SSP juga dilakukan dengan penilaian terhadap hasil posttest siswa.Berikut ini data hasil penilaian guru terhadap SSP yang dikembangkan dan data hasil respon siswa terhadap proses pembelajaran.
Tabel 5. Data Hasil Penilaian Guru dan Respon Siswa Uji Coba Satu-Satu

\begin{tabular}{clcc}
\hline No & $\begin{array}{c}\text { Komponen } \\
\text { SSP }\end{array}$ & $\begin{array}{c}\text { Rerata } \\
\text { Total Skor } \\
\text { Aktual (X) }\end{array}$ & $\begin{array}{c}\text { Kategori } \\
\text { Keefektifan }\end{array}$ \\
\hline 1 & Angket & 219 & Sangat baik \\
2 & penilaian guru & 30 & Sangat baik \\
\hline
\end{tabular}

Pengukuran keefektifan SSP Tematik dalam meningkatkan karakter siswa kelas I SD dilakukan dengan pengisian lembar observasi karakter siswa oleh pengamat, observasi penilaian karakter siswa oleh pengamat, dan penilaian terhadap hasil posttest siswa. Data hasil pengamatan karakter siswa dan data hasil penilaian karakter siswa terlihat pada Tabel 7 dan 8. Penilaian posttest peserta didik akan dibandingkan dengan nilai Kriteria Ketuntasan Minimal (KKM) SDN Wonosari I yakni 75.

Tabel 6. Data Hasil Pengamatan Karakter dan Penilaian Karakter Uji Coba Satu-Satu

\begin{tabular}{clcc}
\hline No & $\begin{array}{c}\text { Komponen } \\
\text { Keefektifan } \\
\text { SSP }\end{array}$ & $\begin{array}{c}\text { Rerata } \\
\text { Skor } \\
\text { Aktual (X) }\end{array}$ & $\begin{array}{c}\text { Kategori } \\
\text { Keefektifan }\end{array}$ \\
\hline \multirow{2}{*}{1} & $\begin{array}{l}\text { Lembar } \\
\text { observasi } \\
\text { karakter }\end{array}$ & 88 & Sangat baik \\
& Lembar & & \\
& Observasi & & \\
2 & Penilaian & & \\
Karakter siswa & 30 & Sangat baik \\
& Jujur & Sangat baik \\
\hline
\end{tabular}

Tabel 7. Data Hasil Posttest Siswa Uji Coba SatuSatu

\begin{tabular}{ccc}
\hline $\begin{array}{c}\text { No. Urut Peserta } \\
\text { Didik }\end{array}$ & $\begin{array}{c}\text { Skor } \\
\text { Posttest }\end{array}$ & $\begin{array}{c}\text { Kriteria } \\
\text { Ketuntasan }\end{array}$ \\
\hline 24 & 100 & Tuntas \\
32 & 100 & Tuntas \\
67 & 100 & Tuntas \\
\hline
\end{tabular}

Data Uji Coba Kelompok Kecil

Uji coba kelompok kecil dilakukan untuk memperoleh data terkait SSP yang dikembangkan. berjumlah 10 siswa yang tidak terlibat uji coba satu-satu. Hasil yang diperoleh pada uji coba kelompok kecil berupa data mengenai keefektifan SSP.

Pengukuran tingkat keefektifan SSP dilakukan dengan cara pengisian angket penilaian guru terhadap SSP dan respon siswa terhadap proses pembelajaran, pengisian lembar observasi karakter siswa oleh pengamat dan 
observasi penilaian karakter oleh observer. Selain itu, pengukuran keefektifan SSP juga dilakukan dengan penilaian terhadap hasil posttest siswa.

Pengukuran keefektifan SSP Tematik untuk meningkatkan kejujuran dan kedisiplinan siswa kelas I SD dilakukan dengan pengisian angket penilaian guru terhadap SSP yang dikembangkan dan respon siswa terhadap proses pembelajaran. Data hasil penilaian guru terhadap SSP yang dikembangkan dan data hasil respon siswa seperti yang terlihat pada Tabel 9.

Tabel 8. Data Hasil Angket Penilaian Guru dan Respon Siswa Uji Coba Kelompok Kecil

\begin{tabular}{rlcc}
\hline No & $\begin{array}{c}\text { Komponen } \\
\text { SSP }\end{array}$ & $\begin{array}{c}\text { Rerata } \\
\text { Total Skor } \\
\text { Aktual }\end{array}$ & $\begin{array}{c}\text { Kategori } \\
\text { Kepraktisan }\end{array}$ \\
\hline 1 & $\begin{array}{l}\text { Angket } \\
\text { penilaian } \\
\text { guru }\end{array}$ & 216 & Sangat baik \\
2 & $\begin{array}{l}\text { Angket } \\
\text { respon siswa }\end{array}$ & 29,7 & Sangat baik \\
\hline
\end{tabular}

Pengukuran keefektifan SSP tematik dalam meningkatkan karakter siswa kelas I SD dilakukan dengan pengisian lembar pengamatan karakter siswa, observasi karakter siswa, dan penilaian terhadap hasil posttest siswa. Data hasil pengamatan karakter siswa dan data hasil penilaian karakter siswa pada Tabel 10. Penilaian posttest siswa dibandingkan dengan nilai
Kriteria Ketuntasan Minimal (KKM) yang ditetapkan, yakni 75 . Data hasil penilaian posttest siswa dapat dilihat pada Tabel 11.

Tabel 9. Data Hasil Posttest Siswa Uji Coba Kelompok Kecil

\begin{tabular}{ccc}
\hline $\begin{array}{c}\text { No. Urut Peserta } \\
\text { Didik }\end{array}$ & $\begin{array}{c}\text { Skor } \\
\text { Posttest }\end{array}$ & $\begin{array}{c}\text { Kriteria } \\
\text { Ketuntasan }\end{array}$ \\
\hline 6 & 93 & Tuntas \\
7 & 93 & Tuntas \\
16 & 100 & Tuntas \\
35 & 93 & Tuntas \\
50 & 100 & Tuntas \\
51 & 100 & Tuntas \\
52 & 100 & Tuntas \\
59 & 93 & Tuntas \\
68 & 100 & Tuntas \\
75 & 100 & Tuntas \\
\hline
\end{tabular}

Data Uji Coba Lapangan

SSP yang telah direvisi kemudian diujicobakan pada uji coba lapangan. Data uji coba lapangan berupa angket penilaian guru, respon siswa terhadap pembelajaran, lembar observasi karakter, lembar observasi penilaian karakter, dan hasil penilaian pretest dan posttest. Ringkasan data hasil pengukuran keefektifan SSP penilaian guru dan respon siswa dapat dilihat pada Tabel 12.

Tabel 10. Data Hasil Pretest dan Posttest Siswa Uji Coba Lapangan

\begin{tabular}{|c|c|c|c|c|c|c|}
\hline \multirow{2}{*}{$\begin{array}{l}\text { Nomor Urut } \\
\text { Siswa }\end{array}$} & \multicolumn{3}{|c|}{ Pretest } & \multicolumn{3}{|c|}{ Posttest } \\
\hline & Nilai & KKM & Kategori & Nilai & KKM & Kategori \\
\hline 28 & 93 & 75 & Tuntas & 93 & 75 & Tuntas \\
\hline 29 & 87 & 75 & Tuntas & 100 & 75 & Tuntas \\
\hline 30 & 80 & 75 & Tuntas & 100 & 75 & Tuntas \\
\hline 31 & 67 & 75 & Tidak Tuntas & 73 & 75 & Tidak Tuntas \\
\hline 33 & 87 & 75 & Tuntas & 100 & 75 & Tuntas \\
\hline 34 & 93 & 75 & Tuntas & 100 & 75 & Tuntas \\
\hline 36 & 87 & 75 & Tuntas & 93 & 75 & Tuntas \\
\hline 37 & 93 & 75 & Tuntas & 100 & 75 & Tuntas \\
\hline 38 & 93 & 75 & Tuntas & 100 & 75 & Tuntas \\
\hline 39 & 80 & 75 & Tuntas & 100 & 75 & Tuntas \\
\hline 40 & 73 & 75 & Tuntas & 93 & 75 & Tuntas \\
\hline 41 & 80 & 75 & Tuntas & 93 & 75 & Tuntas \\
\hline 42 & 73 & 75 & Tidak Tuntas & 93 & 75 & Tuntas \\
\hline 43 & 93 & 75 & Tuntas & 93 & 75 & Tuntas \\
\hline 44 & 93 & 75 & Tuntas & 93 & 75 & Tuntas \\
\hline 45 & 93 & 75 & Tuntas & 100 & 75 & Tuntas \\
\hline 46 & 93 & 75 & Tuntas & 100 & 75 & Tuntas \\
\hline 47 & 93 & 75 & Tuntas & 93 & 75 & Tuntas \\
\hline
\end{tabular}




\begin{tabular}{|c|c|c|c|c|c|c|}
\hline \multirow{2}{*}{$\begin{array}{c}\text { Nomor Urut } \\
\text { Siswa }\end{array}$} & \multicolumn{3}{|c|}{ Pretest } & \multicolumn{3}{|c|}{ Posttest } \\
\hline & Nilai & KKM & Kategori & Nilai & KKM & Kategori \\
\hline 48 & 73 & 75 & Tidak Tuntas & 93 & 75 & Tuntas \\
\hline 49 & 93 & 75 & Tuntas & 100 & 75 & Tuntas \\
\hline 53 & 93 & 75 & Tuntas & 100 & 75 & Tuntas \\
\hline 54 & 93 & 75 & Tuntas & 100 & 75 & Tuntas \\
\hline 55 & 93 & 75 & Tuntas & 100 & 75 & Tuntas \\
\hline 56 & 93 & 75 & Tuntas & 100 & 75 & Tuntas \\
\hline 57 & 100 & 75 & Tuntas & 100 & 75 & Tuntas \\
\hline 58 & 93 & 75 & Tuntas & 100 & 75 & Tuntas \\
\hline 60 & 93 & 75 & Tuntas & 100 & 75 & Tuntas \\
\hline 61 & 100 & 75 & Tuntas & 100 & 75 & Tuntas \\
\hline 62 & 93 & 75 & Tuntas & 93 & 75 & Tuntas \\
\hline 63 & 80 & 75 & Tuntas & 93 & 75 & Tuntas \\
\hline 64 & 87 & 75 & Tuntas & 100 & 75 & Tuntas \\
\hline 65 & 87 & 75 & Tuntas & 100 & 75 & Tuntas \\
\hline 66 & 67 & 75 & Tidak Tuntas & 80 & 75 & Tuntas \\
\hline 69 & 93 & 75 & Tuntas & 100 & 75 & Tuntas \\
\hline 70 & 87 & 75 & Tuntas & 93 & 75 & Tuntas \\
\hline 71 & 93 & 75 & Tuntas & 100 & 75 & Tuntas \\
\hline 72 & 93 & 75 & Tuntas & 100 & 75 & Tuntas \\
\hline 73 & 87 & 75 & Tuntas & 100 & 75 & Tuntas \\
\hline 74 & 100 & 75 & Tuntas & 100 & 75 & Tuntas \\
\hline 76 & 87 & 75 & Tuntas & 87 & 75 & Tuntas \\
\hline 77 & 100 & 75 & Tuntas & 100 & 75 & Tuntas \\
\hline 78 & 93 & 75 & Tuntas & 93 & 75 & Tuntas \\
\hline 79 & 93 & 75 & Tuntas & 80 & 75 & Tuntas \\
\hline 80 & 93 & 75 & Tuntas & 100 & 75 & Tuntas \\
\hline 81 & 93 & 75 & Tuntas & 100 & 75 & Tuntas \\
\hline 82 & 100 & 75 & Tuntas & 100 & 75 & Tuntas \\
\hline 83 & 93 & 75 & Tuntas & 100 & 75 & Tuntas \\
\hline Jumlah Nilai & 4.194 & & & 4.529 & & \\
\hline Rerata & 89,23 & & & 96,44 & & \\
\hline
\end{tabular}

Tabel 11. Data Hasil Angket Penilian Guru dan Respon Siswa Uji Coba Lapangan

\begin{tabular}{llcl}
\hline No. & Komponen Penilaian & Rerata Total Skor Aktual $(\mathbf{X})$ & Kategori Keefektifan \\
\hline 1 & Penilaian guru & 219,5 & Sangat Baik \\
2 & Respon siswa & 29,8 & Sangat Baik \\
\hline
\end{tabular}

Pengukuran keefektifan SSP dilakukan dengan pengisian lembar observasi karakter siswa, pengisian lembar observasi penilaian karakter siswa, dan penilaian hasil pretest dan posttest siswa.
Tabel 12. Data Hasil Observasi Karakter dan Penilaian karakter Siswa Uji Coba Lapangan

\begin{tabular}{clcl}
\hline No & $\begin{array}{c}\text { Komponen } \\
\text { Keefektifan SSP }\end{array}$ & $\begin{array}{c}\text { Rerata } \\
\text { Total } \\
\text { Skor } \\
\text { Aktual }\end{array}$ & $\begin{array}{c}\text { Kategori } \\
\text { Keefektifan }\end{array}$ \\
\hline 1 & $\begin{array}{l}\text { Lembar observasi } \\
\text { karakter }\end{array}$ & 87,5 & Sangat baik \\
& Lembar Observasi & & \\
& Penilaian Karakter & & \\
2 & siswa & 29,85 & Sangat baik \\
& Jujur & 14,8 & Sangat baik \\
\hline & Disiplin & & \\
\hline
\end{tabular}


Pengukuran keefektifan SSP selain hasil pengamatan karakter dan hasil penilaian karakter siswa adalah hasil pretest dan posttest siswa. Penilaian keefektifan dilakukan dengan pemberian penilaian ketuntasan belajar siswa. Data Hasil pretest dan posttest siswa uji coba lapangan pada Tabel 12.

Analisis Data

Analisis data hasil uji coba SSP terdiri dari: (1) analisis data hasil validasi ahli mata pelajaran, (2) analisis data hasil validasi ahli media, (3) analisis data hasil uji coba satu-satu, (4) analisis data hasil uji coba kelompok kecil, dan (5) analisis data hasil uji coba lapangan.

Hasil validasi dari ahli mata pelajaran dapat diketahui tingkat kelayakan SSP yang dikembangkan. Diketahui bahwa rata-rata skor setiap komponen SSP berada pada kategori sangat baik dan baik dengan rincian hasil penilaian silabus berkategori baik; hasil penilaian RPP berkategori sangat baik; hasil penilaian LKS berkategori sangat baik; dan hasil penilaian lembar penilaian berkategori sangat baik. Hasil validasi dari ahli media dapat diketahui tingkat kevalidan SSP yang dikembangkan. Data berupa skor hasil penilaian yang menjadi skor aktual terlihat seperti pada Tabel 12. Berdasarkan Tabel 12 diketahui bahwa jumlah skor perangkat SSP berada pada kategori baik .Hal ini mengindikasikan bahwa meskipun terdapat berbagai revisi berdasarkan saran dan masukan dari validator, produk awal SSP sudah layak digunakan untuk uji coba

Analisis Data Keefektifan SSP Hasil Uji Coba Satu-Satu

Keefektifan SSP diketahui dengan pengisian lembar penilaian guru terhadap SSP oleh guru kelas I dan pengisian respon siswa terhadap proses pembelajaran yang berlangsung. Total skor aktual penilaian guru terhadap SSP adalah 218. Total skor aktual kemudian dikonversi menjadi data skala lima. Berdasarkan hasil analisis, total skor aktual penilaian guru yang diperoleh pada uji coba satu-satu ini berada pada interval berkategori baik. Hal ini memberikan informasi bahwa SSP efektif digunakan dalam pembelajaran.

Tingkat respon siswa terhadap SSP melalui proses pembelajaran. Data hasil respon siswa kemudian dianalisis dengan cara dikonversikan menjadi data skala lima. Respon siswa terhadap SSP yang dikembangkan rata-rata berkategori sangat baik. Seluruh siswa menya- takan bahwa SSP yang dikembangkan berkategori sangat baik.Hasil analisis rerata total skor aktual respon siswa yang dikonversikan menjadi data skala lima juga menyimpulkan bahwa SSP berada pada kategori sangat baik yang mengindikasikan bahwa SSP memenuhi syarat keefektifan.

Berdasarkan hasil analisis dari kedua komponen keefektifan SSP menunjukkan bahwa $S S P$ yang dikembangkan berkategori sangat baik. Selain itu jumlah siswa yang menilai SSP berkategori sangat baik telah memenuhi syarat keefektifan yaitu lebih dari $80 \%$. Oleh karena itu, dapat disimpulkan bahwa SSP yang diukur melalui komponen penilaian guru dan respon siswa pada uji coba satu-satu memenuhi kategori keefektifan.

Kriteria keefektifan SSP juga diukur melalui penilaian terhadap tes hasil belajar, pengamatan karakter, dan penilaian karakter siswa. Hasil penilaian belajar tuntas mengikuti penilaian tes hasil belajar. Hal ini mengindikasikan bahwa SSP yang dikembangkan terbukti efektif dilaksanakan karena semua $(100 \%)$ siswa berhasil tuntas mengerjakan tes yang diberikan.

Pengukuran tingkat keefektifan SSP komponen observasi karakter siswa. Data hasil penilaian karakter siswa kemudian dikonversikan menjadi data skala lima. Hasil analisis total skor aktual penilaian karakter untuk pengamatan karakter siswa berkategori sangat baik. Begitu pula hasil penilaian karakter jujur berkategori sangat baik dan disiplin juga berkategori sangat baik.

\section{Analisis Data Keefektifan SSP Uji Kelompok Kecil}

Tujuan dilaksanakannya uji coba ini adalah untuk mengumpulkan informasi berupa tingkat keefektifan SSP yang dapat digunakan sebagai bahan untuk memperbaiki produk dalam analisis revisi berikutnya. Informasi yang terkumpul selama uji coba kelompok kecil berupa hasil penilaian guru, hasil respon siswa, data pengamatan karakter siswa, penilaian karakter siswa, dan hasil penilaian tes akhir (posttest). Analisis secara lengkap dari masing-masing data tersebut adalah sebagai berikut.

Keefektifan SSP diketahui dengan pengisian lembar penilaian guru terhadap SSP oleh guru kelas I dan pengisian respon siswa terhadap proses pembelajaran yang berlangsung oleh siswa kelas I. Diketahui total skor aktual penilaian guru terhadap SSP adalah 216. Total 
skor aktual kemudian dikonversi menjadi data skala lima. Berdasarkan hasil analisis, total skor aktual penilaian guru yang diperoleh pada uji coba kelompok kecil ini berada pada interval berkategori sangat baik. Hal ini mem-berikan informasi bahwa SSP dinilai efektif digunakan dalam pembelajaran.

Kriteria keefektifan SSP juga dilihat dari tingkat respon siswa terhadap SSP melalui proses pembelajaran. Data hasil respon siswa pada uji coba kelompok kecil terhadap SSP yang dikembangkan rata-rata berkategori sangat baik. Seluruh siswa menyatakan bahwa SSP yang dikembangkan berkategori sangat baik.

Berdasarkan hasil analisis dari kedua komponen keefektifan SSP menunjukkan bahwa $S S P$ yang dikembangkan berkategori sangat baik. Selain itu jumlah siswa yang menilai $S S P$ berkategori sangat baik telah memenuhi syarat keefektifan yaitu lebih dari $80 \%$. Oleh karena itu, dapat disimpulkan bahwa SSP yang diukur melalui komponen penilaian guru dan respon siswa pada uji coba kelompok kecil memenuhi kategori efektif.

Kriteria keefektifan SSP juga diukur melalui penilaian terhadap tes hasil belajar Semua siswa tuntas mengikuti penilaian tes hasil belajar. Hal ini mengindikasikan bahwa SSP yang dikembangkan terbukti efektif karena semua (100\%) siswa berhasil tuntas mengerjakan dengan benar tes yang diberikan.

Pengukuran tingkat keefektifan SSP juga dilakukan pada komponen pengamatan karakter siswa. Data hasil penilaian karakter siswa kemudian dikonversikan menjadi data skala lima. Hasil observasi pada siswa untuk masing-masing karakter termasuk berkategori sangat baik.Hasil penilaian karakter jujur siswa oleh observer termasuk berkategori sangat baik.Hasil penilaian karakter disiplin siswa oleh observer ke dalam bentuk diagram termasuk berkategori sangat baik.

Berdasarkan hasil analisis yang telah dilakukan menunjukkan bahwa hasil penilaian terhadap hasil belajar (posttest), observasi karakter, dan penilaian karakter siswa rata-rata berkategori sangat baik. Jumlah siswa yang memenuhi kategori sangat baik pada masingmasing komponen juga lebih dari $80 \%$. Dengan demikian, dapat disimpulkan bahwa SSP yang dikembangkan dan diujikan pada kelompok kecil efektif digunakan untuk meningkatkan karakter siswa.
Analisis Data Kefektifan SSP Uji Coba Lapangan

Uji coba lapangan dilakukan pada siswa kelas I. B terdiri dari 23 siswa dan 24 siswa kelas I. C SDN Wonosari I Gunungkidul Yogyakarta. Uji coba lapangan dilakukan menggunakan SSP dalam pembelajarannya. Adapun metode yang digunakan dalam uji coba lapang-an adalah metode eksperimen dengan menggunakan desain pretest-posttest control group.

Uji coba lapangan dilaksanakan untuk mengetahui pengaruh tingkat keefektifan SSP. Selain itu, uji coba lapangan merupakan pengujian produk hasil revisi dan evaluasi yang telah dilaksanakan pada uji coba satu-satu dan uji coba kelompok kecil. Berbagai temuan yang dihasilkan pada uji coba lapangan dijadikan bahan evaluasi untuk perbaikan agar menghasilkan SSP yang lebih baik. Hasil analisis terhadap data yang diperoleh pada uji coba lapangan akan dijelaskan sebagai berikut

Kriteria keefektifan SSP diperoleh dengan pengisian lembar penilaian guru terhadap SSP oleh guru kelas I.B, Kelas I.C dan pengisian respon siswa terhadap proses pembelajaran yang berlangsung oleh siswa kelas I.B dan I.C. Hasil penilaian guru terhadap SSP untuk masing-masing komponen SSP dapat dilihat pada Gambar 1 .

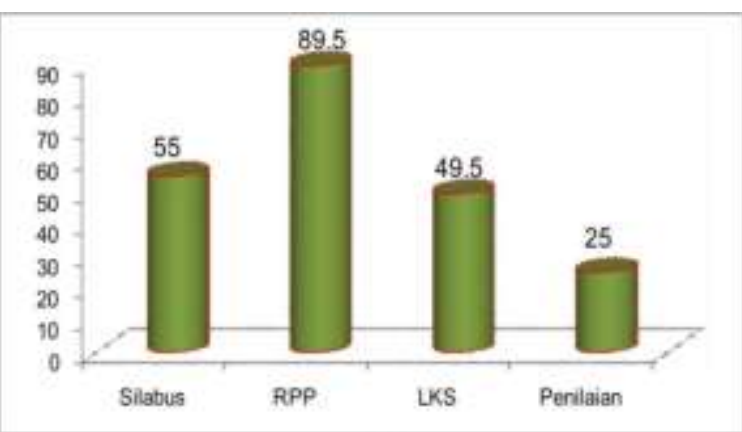

Gambar 1. Diagram Keefektifan SSP Penilaian Guru Uji Coba Lapangan

Seperti yang terlihat pada Gambar 1 dapat diketahui rerata total skor aktual penilaian 2 guru terhadap SSP adalah 219,5. Total skor aktual kemudian dikonversi menjadi data skala lima. Berdasarkan hasil analisis, total skor aktual penilaian guru yang diperoleh pada uji coba lapangan ini berada pada interval berkategori sangat baik. Hal ini mengindikasikan bahwa SSP dinilai efektif digunakan dalam pembelajaran. 
Kriteria keefektifan SSP juga dilihat dari tingkat respon siswa terhadap SSP melalui proses pembelajaran yang mereka alami. Data hasil respon siswa kemudian dianalisis dengan cara dikonversikan menjadi data skala lima. Hasil analisis respon siswa pada uji coba lapangan dapat dilihat pada Gambar 2.
Berdasarkan Gambar 2, respon siswa terhadap SSP yang dikembangkan rata-rata berkategori sangat baik. Sebanyak 47 siswa menyatakan bahwa SSP yang dikembangkan berkategori sangat baik sementara tidak ada siswa yang menyatakan lainnya; seperti baik, cukup baik, kurang baik ataupun sangat kurang baik.

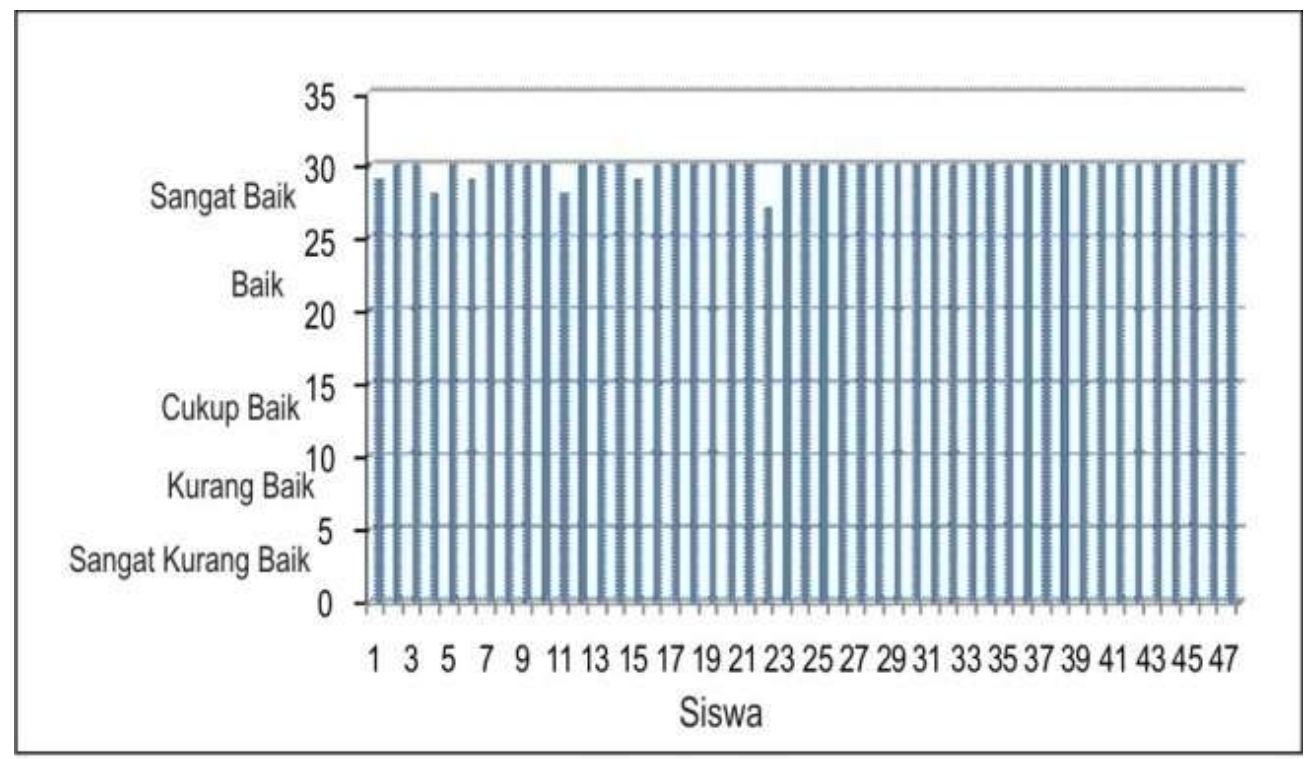

Gambar 2. Diagram Keefektifan SSP Respon Siswa Uji Coba Lapangan

Berdasarkan hasil analisis dari kedua komponen keefektifan SSP menunjukkan bahwa SSP yang dikembangkan berkategori sangat baik. Selain itu jumlah siswa yang menilai SSP berkategori sangat baik telah memenuhi syarat efektif yaitu lebih dari $80 \%$. Oleh karena itu, dapat disimpulkan bahwa SSP yang diukur melalui komponen penilaian guru dan respon siswa pada uji coba lapangan memenuhi kategori efektif.

Keefektifan SSP yang dikembangkan bisa diketahui juga dari tes hasil belajar, hasil pengamatan karakter siswa, dan penilaian karakter siswa. Data tes hasil belajar siswa berupa pretest dan posttest uji coba lapangan. Data hasil pretest dan posttest saat uji coba lapangan akan dianalisa untuk mengetahui keefektifan penggunaan SSP dalam pembelajaran. Analisis data untuk mengetahui pengaruh penggunaan $S S P$ dilakukan dengan cara membandingkan rata-rata skor posttest dengan pretest. Sedangkan analisa data untuk mengetahui tingkat keefektifan penggunaan SSP dalam pembelajaran dilakukan dengan memperhatikan jumlah persentase siswa yang tuntas. Hasil analisis data skor rata-rata posttest dan prestest uji coba lapangan dapat dilihat pada Tabel 13.
Tabel 13. Data Hasil Analisis Rata-Rata Skor Pretest dan Posttest Siswa Uji Coba Lapangan

\begin{tabular}{cc}
\hline Perlakuan & Rata-Rata Skor \\
\hline Pretest & 89,23 \\
Posttest & 96,36 \\
Beda & 7,13 \\
\hline
\end{tabular}

Pada Tabel 15 terlihat bahwa terdapat perbedaan rata-rata skor pretest dan posttest uji coba lapangan. Beda rata-rata skor posttest terhadap prestest pada uji coba lapangan adalah 7,13 poin. Hal ini mengindikasikan bahwa penggunaan SSP berpengaruh meningkatkan pemahaman siswa sebesar 7,13 poin.

Selain untuk mengetahui keefektifan penggunaan SSP dalam pembelajaran, data skor pretest dan posttest siswa pada uji coba lapangan juga digunakan untuk mengetahui tingkat keefektifan penggunaan SSP dalam meningkatkan karakter siswa. Diagram persentase siswa yang tuntas mengerjakan posttest seperti yang terlihat pada Gambar 3. 


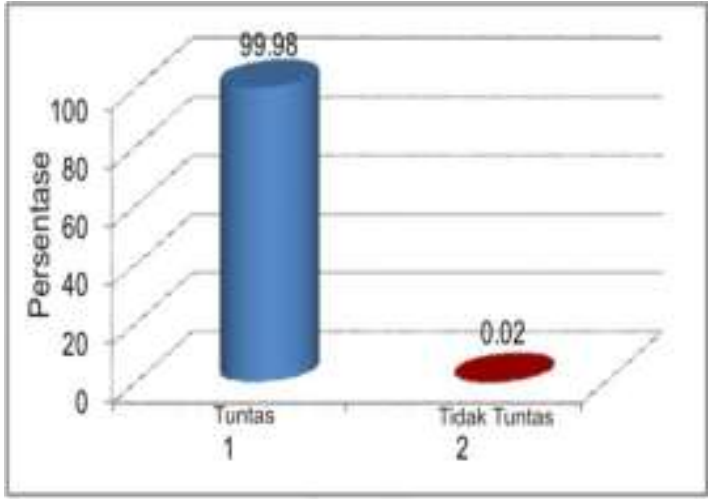

Gambar 3. Diagram Keefektifan SSP Ketuntasan Belajar Siswa Uji Coba Lapangan

Berdasarkan Gambar 3 dapat diketahui bahwa persentase siswa yang tuntas pada uji coba lapangan sebesar 99,98\%. Hasil ini mengindikasikan dua penjelasan yakni: (1) SSP yang digunakan terbukti efektif dilaksanakan karena lebih dari $80 \%$ siswa tuntas melaksanakan pembelajaran dan (2) SSP yang dikembangkan mampu meningkatkan pemahaman siswa terhadap materi pelajaran karena persentase siswa yang tuntas pada uji coba lapangan hampir $100 \%$. Dari hasil analisis terhadap tes hasil belajar pada uji coba lapangan dapat diambil kesimpulan bahwa pada komponen tes hasil belajar SSP yang dikembangkan berkategori efektif sekaligus dapat meningkatkan pemahaman siswa.

Komponen lain yang digunakan dalam mengukur tingkat keefektifan SSP adalah hasil observasi siswa. Data hasil pengamatan tersebut dikonversikan menjadi data skala lima. Hasil analisis data pengamatan kedua jenis karakter siswa pada uji coba lapangan dapat dilihat masing-masing pada Gambar 4.

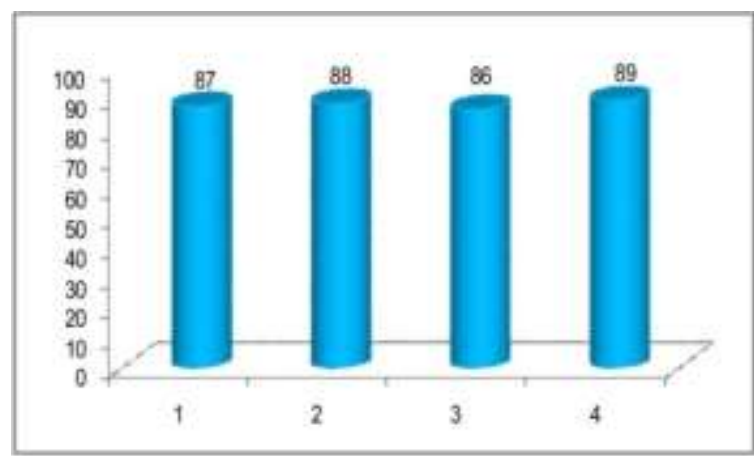

Gambar 4. Diagram Keefektifan SSP Hasil Observasi Karakter Siswa

Pada gambar 4 terlihat bahwa jumlah skor empat siswa masing-masing adalah 87,88 , 86, dan 89. Hal ini mengindikasikan bahwa penggunaan SSP meningkatkan karakter siswa.

Komponen lain yang digunakan dalam mengukur tingkat keefektifan SSP adalah hasil rerata observasi penilaian karakter jujur dan disiplin siswa. Data hasil pengamatan tersebut dikonversikan menjadi data skala lima. Hasil analisis data pengamatan kedua jenis karakter siswa pada uji coba lapangan dapat dilihat pada Gambar 5 dan 6.

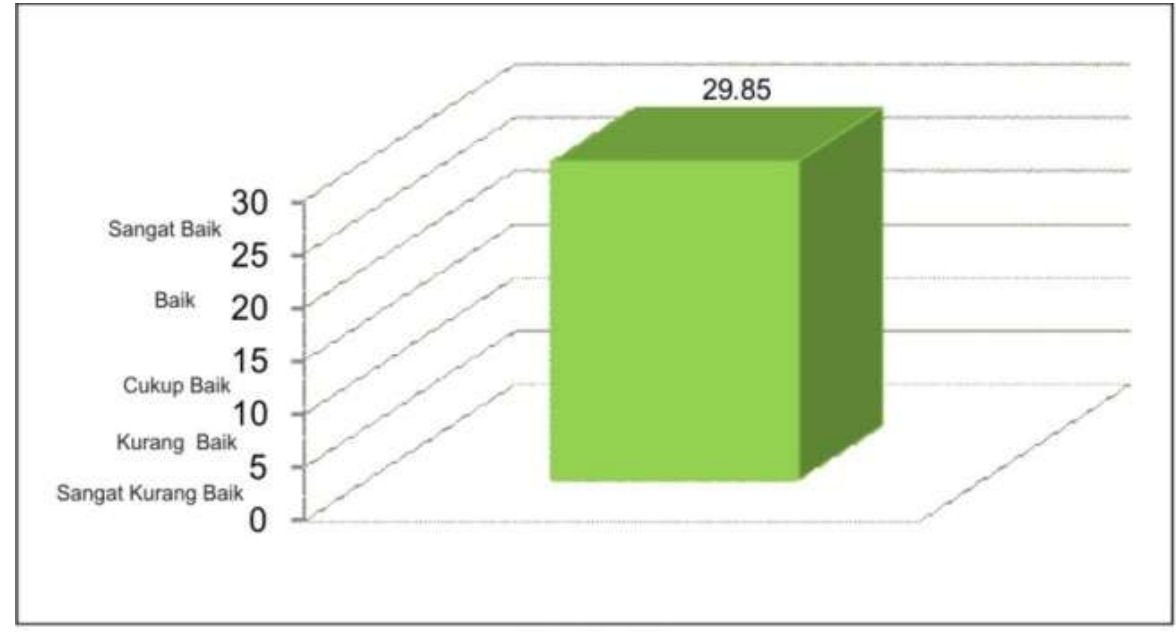

Gambar 5. Diagram Rerata Keefektifan SSP Hasil Penilaian Karakter Jujur Uji Coba lapangan 


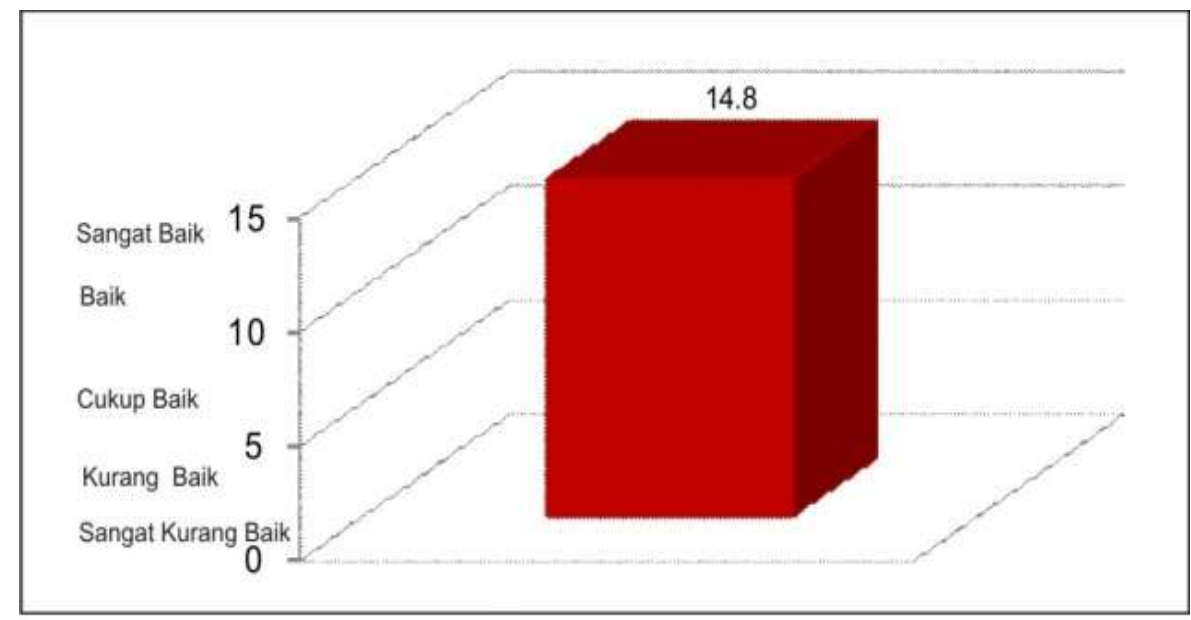

Gambar 6. Diagram Rerata Keefektifan SSP Penilaian Karakter Disiplin Uji Coba lapangan

Gambar 5 dan 6 menunjukan rerata karakter jujur dan disiplin berkategori sangat baik. Karakter jujur reratanya sebesar 29,85. Karakter disiplin reratanya sebesar 14,8 . Hal ini menunjukkan bahwa penggunaan SSP meningkatkan karakter siswa.
Sementara itu hasil analisis data penilaian kedua jenis karakter siswa pada uji coba lapangan dapat dilihat masing-masing pada Gambar 7, dan Gambar 8.

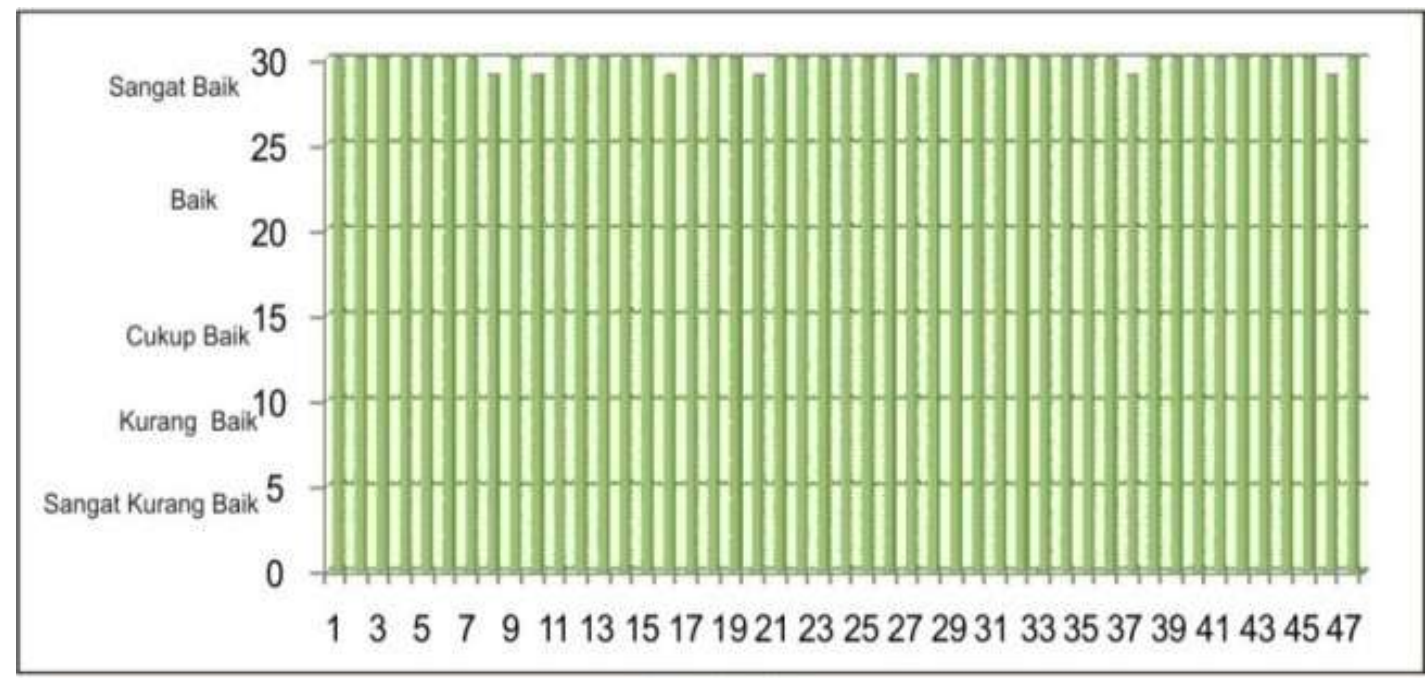

Gambar 7. Diagram Keefektifan SSP Hasil Penilaian karakter Jujur Uji Coba Lapangan

Gambar 7 menunjukan bahwa jumlah siswa berkarakter jujur berkategori sangat baik berjumlah 47 siswa. Hal ini menunjukkan bahwa penggunaan SSP efektif meningkatkan karakter jujur siswa. 


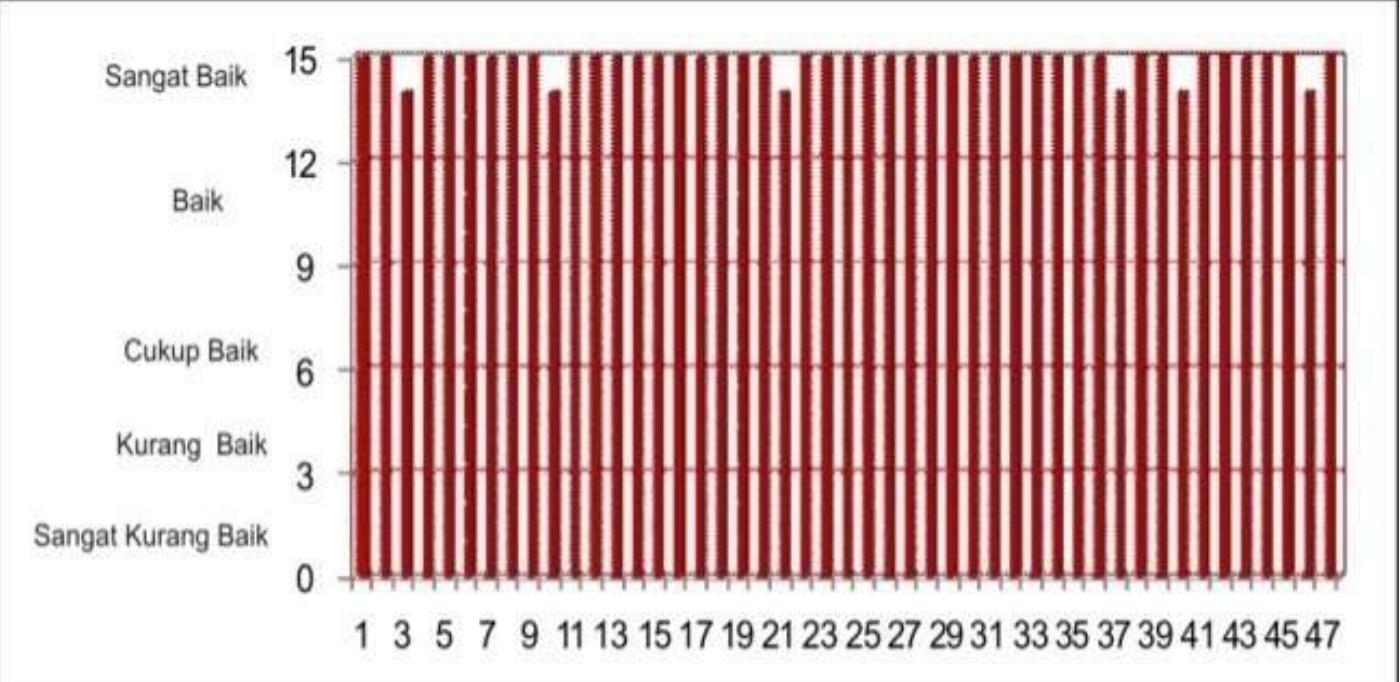

Gambar 8 Diagram Keefektifan SSP Hasil Penilaian karakter Disiplin Uji Coba Lapangan

Berdasarkan Gambar 6 uji coba lapangan rerata total skor aktual karakter jujur adalah 29,85 . Hal ini mengindikasikan bahwa pelaksanaan pembelajaran dengan SSP dapat meningkatkan kejujuran. Rerata total skor aktual karakter jujur sebesar 29,85 berada pada kategori sangat baik. Hal ini menunjukkan bahwa SSP yang digunakan dalam pembelajaran terbukti meningkatkan kejujuran.

Rerata total skor aktual karakter disiplin adalah 14,8. Hal ini mengindikasikan bahwa pelaksanaan pembelajaran dengan SSP dapat meningkatkan kedisiplinan. Rerata total skor aktual karakter disiplin 14,8 berada pada kategori sangat baik. Hal ini menunjukkan bahwa SSP yang digunakan dalam pembelajaran juga terbukti meningkatkan kedisiplinan.

Berdasarkan hasil analisis yang telah dilakukan menunjukkan bahwa hasil belajar (pretest-posttest), observasi karakter, dan penilaian karakter siswa dapat disimpulkan bahwa SSP yang dikembangkan dan diujikan pada uji coba lapangan terbukti meningkatkan karakter siswa. Hasil analisis juga mengindikasikan bahwa dengan metode pembelajaran kooperatif (work group) yang menitikberatkan pada strategi diskusi sangat baik bagi murid dalam memahami isi dan proses dari Tematik serta dapat mengembangkan karakter siswa. Hal ini senada dengan pernyataan Chiappetta \& Koballa (2010,p.74) menuliskan bahwa, group work can be a powerful strategy to learn science content and process, promote good working habits, and cooperation, and to build a positive classroom atmosphere. Dengan demikian SSP Tematik untuk meningkatkan keju- juran dan kedisiplinan terbukti layak dan efektif untuk meningkatkan kejujuran, dan kedisiplinan siswa kelas I SD.

\section{Simpulan dan Saran}

Simpulan Tentang Produk

Berdasarkan hasil penelitian dan pembahasan maka dapat diambil kesimpulan sebagai berikut:

Pengembangan SSP Tematik untuk meningkatkan kejujuran dan kedisiplinan diawali dengan tahap definisi yakni melakukan analisis siswa, analisis kurikulum, analisis materi, peta materi, dan analisis jenis perangkat; tahap desain yakni melakukan pemilihan format, penentuan perangkat pembelajaran, dan perancangan $S S P$; tahap pengembangan yakni pengembangan produk awal yaitu validasi ahli dan uji coba satu-satu, uji coba kelompok kecil, dan tahap uji coba lapangan, sehingga menghasilkan SSP yang berkarakteristik sebagai berikut: (1) $S S P$ yang dikembangkan meliputi silabus, Rencana Pelaksanaan Pembelajaran (RPP), Lembar Kerja Siswa (LKS), dan Instrumen penilaian, (2) Silabus terintegrasi antara pembelajaran kognitif dengan pengembangan karakter jujur dan disiplin lengkap dengan indikatornya, (3) RPP terintegrasi antara pembelajaran kognitif dan pengembangan karakter jujur dan disiplin yang tertuang dalam setiap tahapan dalam kegiatan pembelajaran, (4) LKS memuat latihan-latihan aspek kognitif dan latihan pengembangan karakter jujur dan disiplin melalui pesan-pesan yang disisipkan di antara perintah dan kolom kerja siswa. 
Instrumen Penilaian terintegrasi antara instrumen penilaian kognitif dan instrumen pengembangan karakter jujur dan disiplin melalui format dan stem soal yang diisi siswa. (1) SSP yang dikembangkan terdiri atas silabus, RPP, LKS, dan instrumen penilaian menurut ahli mata pelajaran dan ahli media berkategori baik; (2) Berdasarkan penilaian guru dan respon siswa SSP yang dikembangkan dalam penelitian ini terbukti efektif untuk pembelajaran Tematik di kelas I SDN Wonosari I; (3) Pembelajaran dengan menggunakan SSP terbukti efektif meningkatkan karakter siswa kelas I SDN Wonosari I berdasarkan hasil belajar, observasi karakter siswa, dan observasi penilaian karakter siswa.

Adapun saran pemanfaatan, diseminasi, dan pengembangan lebih lanjut adalah: (1) Pengembangan SSP Tematik untuk meningkatkan kejujuran dan kedisiplinan siswa kelas I SD sudah diuji kelayakan dan keefektifannya, maka disarankan kepada guru untuk menggunakan perangkat ini sebagai alternatif pedoman pelaksanaan pembelajaran yang dapat meningkatkan kejujuran dan kedisiplinan siswa; (2) SSP hasil pengembangan diharapkan dapat didesiminasikan di sekolah-sekolah di Indonesia khususnya kelas I SD dan tidak hanya di SD tempat uji coba dilaksanakan. Selanjutnya, untuk SSP sejenis dapat dikembangkan sendiri oleh guru dengan menambah jenis karakter yang diintegrasikan.

\section{Daftar Pustaka}

Bohlin, K.E. (2005). Teaching character education through literature awakening the moral imagination in secondary classrooms. New York: Routledge Falmer.
Borg, W.R., Gall, M.D., \& Gall. J.P. (2003). Educational research: an introduction. $(7$ th Ed). New York: Pearson Education. Inc.

Chiappetta, E.L., \& Koballa, T.R. Jr. (2010). Science instruction in the middle and secondary schools: developing fundamental knowledge and skills. (7th Ed). New York: Pearson International Education. Inc.

Driel, JHV., Verloop, N., \& de Vos, W., (1998). Developing science teachers' pedagogical content knowledge [Versi Elektronik]. Journal of research in science teaching. 35, 673-695.

Hurlock (2002). Perkembangan anak, jilid 1. Jakarta: Erlangga

Lickona, T. (1991). Educating for character: How our schools can teach respect and responsibility. New York: Bantam Books.

Pusat Kurikulum (2009). Pengembangan dan Pendidikan Budaya dan Karakter Bangsa: Pedoman Sekolah. Jakarta

Rencana Strategis Departemen Pendidikan Nasional tahun 2010-2014. Jakarta: Depdiknas

Schunk, DH. (2012). Teori-teori pembelajaran: perspektif pendidikan. Yogyakarta: Pustaka Pelajar

Slavin, RE. (2011). Psikologi pendidikan: teori dan praktik (edisi ke-9). Slavin, R.E. terjemahan. Jakarta Barat: PT Indeks. 